\title{
A New Case of Scientific Dishonesty in the Field of Parapsychology
}

\author{
Michael Nahm \\ Institute for Frontier Areas of Psychology and Mental Health (IGPP), Freiburg, Germany \\ nahm@igpp.de
}

Submitted June 26, 2021; Accepted June 28, 2021; Published September 15, 2021

https://doi.org/10.31275/20212237

Creative Commons License CC-BY-NC

\begin{abstract}
The present article informs about a case of prolonged scientific dishonesty in the field of parapsychology. It emerged that Alejandro Parra, an active member of the parapsychological community for about three decades, has published substantially plagiarized books and articles since at least 2006. Currently, I am aware of 22 publications that contain plagiarized sections or that consist almost entirely of plagiarism. In the following, I present striking examples of such plagiarized texts and provide background information about the development of this case. Parra even presented research results obtained by others as his own research results, which amounts to data fabrication. Therefore, I conclude one cannot trust any of his books and articles. Even Parra's publications that contain data obtained in surveys or experimental studies must be disregarded by the scientific community unless the validity of their raw data has been very carefully established by examinations performed by others. Keywords: Plagiarism; parapsychology; Alejandro Parra; fraud
\end{abstract}

I publish this article about a prolonged episode of scientific dishonesty in the field of parapsychology with uneasy feelings. Yet, it is an obligation to write this article in order to inform the public as well as the scientific community about a case of long-standing plagiarism and even data fabrication by a parapsychologist. Hence, the case I present adds to the list of previous instances of scientific dishonesty in our field as exemplified by the cases of Walter J. Levy (Rhine, 1974, 1975) and 
Samuel G. Soal (West \& Markwick, 2018; see also Roe, 2016). These cases are particularly unfortunate because many contemporary scientists regard parapsychological research with considerable skepticism already. Accordingly, the Ethical and Professional Standards for Parapsychologists of the Parapsychological Association state:

The consequences of scientific dishonesty may be especially great in a controversial and widely discussed area such as parapsychology. So, while the importance of truthfulness in any scientific field is fundamental, the secondary effects of a lapse in this regard may be especially great in parapsychology. For such reasons, investigators in this field should be especially circumspect in the conduct and reporting of studies to insure the highest level of accuracy and truthfulness. (Parapsychological Association, 2005)

The case I need to report is even more deplorable as it concerns a past President of the Parapsychological Association (2011-2013) and a long-term member of its Board of Directors (2013-2015; 2018-2020), Alejandro Parra. I first stumbled upon suspicious contributions of his in October 2020 when performing a literature study into exceptional phenomena in near-death states. In a book by Parra about his survey of unusual experiences of Argentinian nurses, The Last Farewell Embrace (Parra, 2019a), I noted a case report that sounded very similar to a case reported from a previous survey conducted in England (Brayne et al., 2008). I present Parra's Argentinian case and the British case below.

A caregiver named Emilia told an extraordinary story of an elderly resident who suffered a severe spinal fusion that left her able to look only towards the floor. "A couple of days before she died," said Emilia, "her head went up and she could look out the window. She [the resident] said, 'I can see the house!' We were so delighted that we moved her to the window, so she could enjoy the view for the first time in years. Shortly after, she died." (Parra, 2019a, p. 69)
Several of the interviewees told the remarkable story of a resident who had severe spinal fusion to the extent the resident could only look at the floor. "A couple of days before she died," said one of the interviewees, "her head was up and she could look out of the window. She [the resident] said 'Oh I can see the house over there." The nurses were so delighted, they wheeled her to the window so she could enjoy the view for the first time in years. She died shortly after. (Brayne et al., 2008, p. 201) 
When I asked Parra about the striking similarity of these two cases, he replied that he had unfortunately been unable to record his interview with Emilia, neither in writing nor via audio recording. But because Emilia's report would have been so similar to the British case, he decided to simply reproduce the version given by Brayne et al. (2008). $\mathrm{He}$ apologized for this unusual conduct (personal communication to the author, October 24, 2020).

Thereafter, taking a closer look into Parra's book, I noted that numerous other cases and text passages also sounded very similar to text contained in other sources. I present a few other examples below.

\begin{tabular}{l|l} 
Many of the stories that emerged & $\begin{array}{l}\text { These dreams and visions were } \\
\text { through my interviews with nurses }\end{array}$ \\
overwhelmingly described as comforting \\
in hospitals and nursing homes were \\
to the patient. For example, I patient \\
particularly moving. For example, a \\
patient often dreamed of her dead sister \\
reported that she had frequent dreams \\
of her dead sister sitting beside her bed. \\
that she herself was younger, that she \\
had gone for a walk and done "the usual \\
things" with her sister. She described \\
going for walks, and doing "the usual \\
these dreams as extremely comforting, with her sister. She described \\
these dreams as extremely comforting \\
because "I'm not going alone . . . [my \\
sister] is with me." (Parra, 2019a, p. 53f) & $\begin{array}{l}\text { sister] will be with me." (Nosek et al., } \\
\text { 2015, p. 3) }\end{array}$
\end{tabular}

A caretaker of a nursing home told me about the following experience where she heard the voice of her deceased father on her mother's deathbed: "I took some time to take care of my mother at home, and, when she died, I had her in my arms. Also present was my brother and a niece. I clearly heard my father's voice calling her right before she died. He had died twenty-four years earlier, so, of course, I was not thinking about him. It may have been in my subconscious, but I clearly heard his voice calling her by her name. It was incredible!" (Parra, 2019a, p. 61)
5.2. Carer hears deceased father's voice at mother's deathbed

'I took time off to nurse my mother at home and when she died, I was holding her in my arms and there was a brother there and a niece and I distinctly heard my father's voice calling her, just at the point of death. He had died some twenty-four years before and he certainly wasn't on my mind, as far as I'm aware. He may have been in my subconscious but I distinctly heard his voice call her name. That was amazing!' (Fenwick et al., 2010, p. 5) 
Stella C., a home nurse, said that these experiences and hallucinations can be the same. She remembered the case of an old woman whose husband had recently died. The wife became ill, and, after returning home, began to call for her deceased husband. "She was always repeating her husband's name, saying, 'Jack, I'm coming,' every time she talked about him. Sometimes I think it's because they have dementia, and that's why they have this kind of hallucination." (Parra, 2019a, p. 65)
Another interviewee said that ELEs and hallucinations might be the same thing. She cited an example of an elderly woman whose husband had died recently. The wife became ill, and after returning to the nursing home from hospital, she began calling out to her dead husband. "She was always saying her husband's name, 'Jack I am coming,' whenever she talked about her husband. I think sometimes it's because they have dementia, and that's the reason they have hallucinations like that." (Brayne et al., 2008, p. 199)
Natalia, a young nurse who had studied psychology, reported: "You can see it in their eyes, in their eyes. When they have a fever, they see things or are agitated or anxious. You can see that there is a fear, something that you do not understand. . . . The end-of-life experience is like a process, and, once you have experienced it, you move into a different mental state. The experience at the end of life is usually something so positive. . . . It's like a trip." (Parra, 2019a, p. 65)
A nurse said, You can tell from their eyes. When they have a high temperature they see things and it's an anxiety-based thing. You can see there's an underlying fear because they don't understand it. . . .Whereas with the end-of-life experience it's like a process and once they have experienced it they move onto a different level. End-of-life experience is usually such a positive thing. It's like a journey. (Brayne et al., 2008, p. 199)
One of them told me: "Sometimes the room was cold. Other times, it was very hot. Opening the window sometimes helps; you calm down by opening the window." Another spoke of a "physical" sensation [. . .] after a resident died. (Parra, 2019a, p. 67)
One said, "Sometimes the room is freezing. At other times it is really, really hot. Opening a window often helps. You feel a calm going out of the window." One care assistant spoke of a physical sensation after one resident died. (Brayne et al., 2008, p. 200)

It is obvious that these texts are very similar, despite the explicit attribution of Parra's cases to his own personal interviews with the nurses and the slightly different wording. This difference in the exact wording might simply be due to translating the original texts into Spanish and then retranslating them back into English, because Parra's book was first published in Spanish before the English edition was issued (Parra, 2019b). 
However, I became even more concerned when I noticed that numerous cases presented in Parra's book were also contained in an article he published in the magazine EdgeScience (Parra, 2018)—and that this article contained additional plagiarism not contained in his book. These text passages were virtually copied verbatim and without attribution. Even worse, they referred directly to the methods applied and the results obtained in his Argentinian survey, but were obviously taken from the already mentioned British survey:

\begin{tabular}{|c|c|}
\hline $\begin{array}{l}\text { After they completed the questionnaire, } \\
\text { those who agreed to an interview } \\
\text { were invited to take part in a tape- } \\
\text { recorded session that lasted between } \\
\text { I and } 1 \text { 1/2 hours. The interviewees } \\
\text { were encouraged to talk freely about } \\
\text { their experiences with dying residents. } \\
\text { These interviews were transcribed } \\
\text { verbatim to enable examination of } \\
\text { how anomalous experiences may have } \\
\text { affected the interviewee personally and } \\
\text { professionally and to explore further } \\
\text { training needs in order to enhance } \\
\text { best practice for end-of-life care. } \\
\text { Potential interviewees were approached } \\
\text { through the management team. Ten } \\
\text { responded, five of whom were trained } \\
\text { nurses, including the matron and } \\
\text { the undermatron, and five were care } \\
\text { assistants, including a care assistant } \\
\text { supervisor. (Parra, } 2018 \text {, p. } 13 \text { ) }\end{array}$ & $\begin{array}{l}\text { After they completed the questionnaire, } \\
\text { the interviewees were invited to take part } \\
\text { in a tape-recorded interview that lasted } \\
\text { between } 1 \text { and } 1 / 2 \text { hours. The interviewees } \\
\text { were encouraged to talk freely about } \\
\text { their experiences, with enough direction } \\
\text { provided to cover the criteria outlined } \\
\text { in the questionnaire. These interviews } \\
\text { were transcribed verbatim to enable } \\
\text { examination of how ELEs may have } \\
\text { affected the interviewee personally and } \\
\text { professionally and to explore further } \\
\text { training needs in order to enhance best } \\
\text { practice in the provision of end-of-life } \\
\text { care. [. . . Potential interviewees were } \\
\text { approached through the management } \\
\text { team. Ten responded, } 5 \text { of whom were } \\
\text { trained nurses, including the matron } \\
\text { and the undermatron, and } 5 \text { were care } \\
\text { assistants, including a care assistant } \\
\text { supervisor. (Brayne et al., } 2008 \text {, p. 197f) }\end{array}$ \\
\hline
\end{tabular}

When I asked Parra to explain this apparent identicalness of these passages, he confessed that he used texts written by others because he was probably under pressure. He apologized and admitted that this may "sound" like plagiarism (personal communication to the author, October 29, 2020). In response, I informed Parra that this practice would not only sound like plagiarism, but would clearly be plagiarism. He never replied to me (I sent my entire correspondence with Parra on this matter to the Editor of this Journal). ${ }^{1}$

Thereafter, I discovered more and more instances of unmistakable plagiarism in Parra's book. Additionally, it contains numerous oddities 
that signify a rather sloppy style of editing the text. For example, an entire page section is accidentally printed twice in slightly different wording, indicating reiterated software processing (Parra, 2019a, p. 5). Page 10 contains an odd and seemingly accidental footnote inserted after the word "Italian"-it is the only footnote in the entire book. Strangely, it neither concerns Italy nor the topics of the main text, but unrelated writings of a French philosopher. What is worse, all English verbatim quotes Parra transferred from the original literature are not verbatim quotes anymore because of their being translated into Spanish and then retranslated back into English. Of course, this resulted in different wording that doesn't necessarily convey the exact meaning anymore, as already evident in some sentences of the examples given above.

Some retranslated text passages even border on the nonsensical, for example when a mist that left the body of a dying person and "lifted itself into an upright position" (Alvarado, 2006, p. 138) turns into a mist that "rose above itself in a vertical position" (Parra, 2019a, p. 15); when visions of "animals, objects, and unformed (e.g., an electric current) perceptions" (Ethier, 2005, p. 109) turn into visions of "animals, objects, and deformations (e.g., an electric current)" (Parra, 2019a, p. 25); or when the dying describe "dead relatives and friends standing at their bedsides, watching over them" (Nosek et al., 2015, p. 4), and this turns into dead relatives and friends of the dying "standing in their beds, watching them" (Parra, 2019a, p. 57). I also wondered that transpersonal experiences such as deathbed visions possess "mundane" qualities that cannot be easily explained by the pathological process of dying (2019a, p. 59), whilst this statement referred to these experiences' "other-worldly" qualities in the original text (Fenwick et al., 2010, p. 2). Parra furthermore informs the reader that anomalous behaviour of "flies" that appear around the dying ranks among the unusual deathrelated phenomena reported by nurses (Parra, 2019a, pp. vii, 59). I never heard of that before-did he perhaps mean "butterflies" (Fenwick et al., 2010)? It is additionally surprising to learn that Janice Miner Holden, a former Professor of Counseling at the University of North Texas, currently President of the International Association for Near-Death Studies, and since 2008 Editor-in-Chief of the Journal of Near-Death Studies, is actually a "nurse" (Parra, 2019a, p. 82).

These examples should suffice to reveal the quality of Parra's book. 
Apart from a section in Chapter 3, each chapter consists almost exclusively of translated and retranslated text of unacknowledged source material written by other authors. Even the Conclusion, in which one might expect to find at least a few personal reflections of the book's author, consists entirely of plagiarism. Appendix 1 contains a list of the original sources used in each chapter of Parra's book.

I duly informed several of the plagiarized authors and editors about these findings. This resulted in the retraction of Parra's English book (Parra, 2019a), the retraction of his article in EdgeScience (Parra, 2018; for the retraction notice see Anonymous, 2021a), the retraction of an article in this Journal about the survey in Argentina (Parra \& Giménez Amarilla, 2017; for the retraction notice see Anonymous, 2021b), the retraction of another article about his survey in the Zeitschrift für Anomalistik (Parra, 2019c; for the retraction notice see Mayer, 2021), and a notice in the magazine Fortean Times (Anonymous, 2021c) highlighting massive plagiarism in one more of Parra's articles on the Argentinian survey (Parra, 2020).

Curiously, however, Parra denied having plagiarized after my conversation with him. In a letter sent to several parapsychologists and some of his supporters on March 8, 2021, he stated that the plagiarism was actually performed by undergraduate students of his, and that he merely published their texts under his own name without knowing that the students' texts contained plagiarism. Nevertheless, it is evident that in numerous instances (I gave some examples above), these texts explicitly state that he interviewed the nurses, and that the nurses told him about their experiences. This is in line with his initial explanation of the Emilia case to me: He informed me that he interviewed Emilia; and he later even confessed having used texts of others, i.e., having plagiarized. Moreover, if this book and all the articles derived from it were really written by his students, and if he published them under his own name thereafter, not even checking and correcting their content, and without naming the true authors, I wonder: Would this be any better from a scientific perspective than merely plagiarizing on one's own?

But the claim that Parra was only misled by his students is questionable, anyway. On further examination, it turned out that numerous other publications by Parra are heavily plagiarized as well, at 
least from 2006 onward. This even includes his Spanish doctoral thesis (Parra, 2011) in which a cursory search identified large sections that were simply translated from Varieties of Anomalous Experience (Cardeña et al., 2000) and other sources such as Alvarado (2006) and Sherwood (2002) without attribution. I don't consider it unlikely that many more publications of Parra contain plagiarized, translated, retranslated, shortened, and/or repeatedly rearranged puzzles of text taken from unnamed or inappropriately cited original literature. At least, I found plagiarized text passages in almost all his publications that I checked, and I strongly doubt that all this was the work of nasty students whose work he published unchecked under his own name since at least 2006. Appendix 2 contains a list of Parra's publications that are currently known to contain plagiarism, sometimes massive.

Given that Parra already knew in the autumn of 2020 that the plagiarism in his book about the Argentinian survey (Parra, 2019a) was spotted, it is furthermore astonishing that a French translation of precisely this book was published in 2021. Before this French version was printed, it was advertised by its publisher in advance. Renaud Evrard, at that time President of the Parapsychological Association, informed this publisher on the 3 rd of December 2020 that the book consisted almost exclusively of proven plagiarism. Consequently, the publisher considered stopping the editing process and intended to contact Parra to clarify the matters. Surprisingly, however, his book was nevertheless published in January (Parra, 2021). Parra even advertised its publication on Facebook. Similarly, Parra was informed in March 2021 that the plagiarism in another recent book of his, Neurociencias (Parra, 2019d), had been spotted as well. This book contains dozens of pages that were simply translated from English sources (e.g., from Krippner \& Friedman, 2010, and most notably from Williams, 2015). Nevertheless, Parra also advertised his spurious Neurociencias book on Facebook on the Argentinian "Writer's day" in 2021, which is celebrated each year on June 13th to honor the work of honest writers.

The fact that Parra continues to publicly promote his known plagiarized texts further, after all that has already happened, shows an astonishing lack of insight that underscores the necessity to publish the present report. This is especially evident because he stressed in his letter to his friends and selected parapsychologists in March 2021 
with regard to the alleged plagiarism of his students "that plagiarism constitutes a serious contradiction of the most elementary rules of scientific conduct, an execrable crime that must be denounced and condemned by the scientific community." However, despite these bold statements, the public as well as the scientific community must obviously be prepared to witness further attempts of Parra to produce and disseminate plagiarized publications-be they initiated by students under his supervision or by himself.

\section{CONCLUDING REMARKS}

It is impossible to avoid the conclusion that Parra's plagiarism was performed purposefully and systematically for many years to obtain personal advantage and fame, even when he published texts about rather sensible topics such as experiences of the dying and the bereaved, what he considered a "great spiritual experience" (Parra, 2019a, p. xiv). Parra also must have known all the time that his conduct might cause considerable damage to parapsychology when uncovered, but he willfully took this risk. In fact, there are allegations against Parra concerning potential scientific dishonesty that date back to 1991 (Gimeno, 2021). Still, it came as a surprise to me that some parapsychologists already knew that Parra had had a habit of plagiarizing for many years. Allegedly, he was repeatedly asked to stop plagiarizing. Nobody, however, seemed to have an appreciable interest in checking his conduct and publications. The result of this curious neglect is plain to see now: Parra simply continued to publish an enormous amount of texts of doubtful origin that must now be prevented from being cited in the downstream literature.

This also goes for the his numerous publications about the surveys and experimental studies he performed. I don't think one can trust data published by a person who has profoundly sympathized with and enacted scientific dishonesty since at least 2006. Moreover, contents of interview reports can also be regarded as data. Therefore, plagiarizing them and presenting them as results obtained in one's own research project even amounts to data fabrication. This was confirmed by Miguel Roig (personal communication to the author, June 25, 2021), an expert on the topic of plagiarism in the sciences (see, e.g., Vasconcelos et al., 
2019). As a consequence, all other data presented by Parra should be disregarded unless one is willing to check his original data records very, very thoroughly, and then finds absolutely nothing to complain about. For my part, I prefer spending my time on numerous much more exciting and rewarding matters.

\section{NOTE}

1 In an explanation termed "An honest reply and clarification" that Parra sent on March 8, 2021, to several of his supporters and other parapsychologists to elucidate how plagiarism entered his writings, he nevertheless presented a rather different version of what happened. He claimed that after I informed him about plagiarized sections in his work, he would have told me that 1 ) these paragraphs were inserted into his texts without his knowledge, and that 2) he wanted to initiate an investigation regarding the origin of this mishap. He furthermore complained that 3) I never responded to him thereafter. Yet, documented email correspondence proves that none of this is true.

\section{ACKNOWLEDGMENTS}

My investigations into the plagiarism of Parra and my attempts to induce an appropriate reaction of the parapsychological community were not always greeted with sympathy. I am therefore immensely grateful to the following colleagues who encouraged my work, providing invaluable moral and practical support of different kinds: Carlos Alvarado, Eberhard Bauer, Stafford Betty, Stephen Braude, Etzel Cardeña, Renaud Evrard, Kathleen Erickson, Wolfgang Fach, Peter Fenwick, Juan Gimeno, Pei Grant, Patrick Huyghe, Christopher Kerr, Stanley Krippner, Gerhard Mayer, Chris Roe, Miguel Roig, Peter Mulacz, Stefan Schmidt, Christine Simmonds-Moore, David Sutton, Doreen Westera, Marc Wittmann, and Ricarda Zöhn.

\section{REFERENCES}

Alvarado, C. S. (2006). Neglected near-death phenomena. Journal of Near-Death Studies, 24(3), 131-151.

Anonymous. (2021a). Retraction notice: Experiences at the end of life in nursing homes by Alejandro Parra, EdgeScience 33, March 2018. EdgeScience, 45, 5. 
Anonymous. (2021b). Retraction of: Parra, A., \& Giménez Amarilla, P. (2017), Anomalous/paranormal experiences reported by nurses in relation to their patients in hospitals, Journal of Scientific Exploration, 31(1), 11-28. Journal of Scientific Exploration, 35(1), 137-140.

Anonymous. (2021c). Dreams, death and plagiarism. Fortean Times, 401, 2.

Brayne, S., Lovelace, H., \& Fenwick, P. (2008). End-of-life experiences and the dying process in a Gloucestershire nursing home as reported by nurses and care assistants. American Journal of Hospice \& Palliative Care, 25(3), 195-206.

Cardeña, E., Lynn, S. J., \& Krippner, S. (Eds.). (2000). Varieties of anomalous experience: Examining the scientific evidence. American Psychological Association.

Ethier, A. (2005). Death-related sensory experiences. Journal of Pediatric Oncology Nursing, 22(2), 104-111.

Fenwick, P., Lovelace, H., \& Brayne, S. (2010). Comfort for the dying: Five year retrospective and one year prospective studies of end of life experiences. Archives of Gerontology and Geriatrics, 51(2), 173-179.

Gimeno, J. (2021, March 9). Los múltiples plagios de Alejandro Parra, la "cara seria" de la parapsicología argentina. Factor 302.4. El Blog de Alejandro Agostinelli. https:/factorelblog.com/2021/03/og/parradoja/

Krippner, S., \& Friedman, H. L. (Eds.). (2010). Mysterious minds: The neurobiology of psychics, mediums, and other extraordinary people. Praeger.

Mayer, G. (2021). Zurückziehung von: Parra, A. (2019), Berichte von Krankenpflegerinnen über außergewöhnliche Erfahrungen-Eine Studie zu Persönlichkeits-, Wahrnehmungs- und kognitiven Faktoren, Zeitschrift für Anomalistik, 19(3), 347-363. Zeitschrift für Anomalistik, 21(1), 334-335.

Nosek, C. L., Kerr, C. W., Woodworth, J., Wright, S. T., Grant, P. C., Kuszczak, S. M., Banas, A., Luczkiewicz, D. L., \& Depner, R. M. (2015). End-of-life dreams and visions: A qualitative perspective from hospice patients. American Journal of Hospice \& Palliative Care, 32(3), 269-274.

Parapsychological Association. (2005). Ethical and Professional Standards for Parapsychologists: Aspirational Guidelines. https://www.parapsych.org/ section/42/ethical_and_professional_standards.aspx

Parra, A. (2011). Percepciones imposibles: Alucinaciones, visiones y experiencias perceptuales inusuales (2nd ed.). Editorial Académica Española. First published in 2009 .

Parra, A. (2018). Experiences at the end of life in nursing homes. EdgeScience, 33 , 12-17. (Retracted by publisher)

Parra, A. (2019a). The last farewell embrace: Spirituality, near-death experiences, and other extraordinary events among nurses. Nova Science Publishers. (Retracted by publisher)

Parra, A. (2019b). El último abrazo de despedida: Experiencias paranormales de enfermeras. Ediciones Luciérnaga. 
Parra, A. (2019c). Berichte von Krankenpflegerinnen über außergewöhnliche Erfahrungen: Eine Studie zu Persönlichkeits-, Wahrnehmungs- und kognitiven Faktoren. Zeitschrift für Anomalistik, 19(3), 347-363. (Retracted by publisher)

Parra, A. (2019d). Neurociencias en la frontera con lo paranormal: Comprender lo inexplicable en las redes del cerebro. Kier.

Parra, A. (2020). Dreams, death and spirituality. Fortean Times, 398, 40-45.

Parra, A. (2021). L'ultime transition: Le monde médical face à l'après-vie. JMG.

Parra, A., \& Giménez Amarilla, P. (2017). Anomalous/paranormal experiences reported by nurses in relation to their patients in hospitals. Journal of Scientific Exploration, 31(1), 11-28. (Retracted by publisher)

Rhine, J. B. (1974). A new case of experimenter unreliability. Journal of Parapsychology, $38,215-225$.

Rhine, J. B. (1975). A second report on a case of experimenter fraud. Journal of Parapsychology, 38, 306-325.

Roe, C. A. (2016). The problem of fraud in parapsychology. Mindfield, 8(1), 8-17.

Sherwood, S. J. (2002). Relationship between the hypnagogic/hypnopompic states and reports of anomalous experience. Journal of Parapsychology, 66, 127-150.

Vasconcelos, S. M. R., Masuda, H., Sorenson, M., Prosdocimi, F., Palácios, M., Watanabe, E., Pinto, J. C., Lapa e Silva, J. R., Vieyra, A., Pinto, A., MenaChalco, J., Sant'Ana, M., \& Roig, M. (2019). Plagiarism in Brazil: A perspective of 25,000 PhD holders across the sciences. BioRxiv, 825026. doi: https://doi. org/10.1101/825026

West, D. J., \& Markwick, B. (2018). Dr Soal: A psychic enigma. Proceedings of the Society for Psychical Research, 6o(224), 1-172.

Williams, B. J. (2015). Psychic phenomena and the brain: Exploring the neuropsychology of psi. Australian Institute of Parapsychological Research.

\section{APPENDIX 1}

\section{Original Sources of Parra's book The Last Farewell Embrace (2019)}

The main plagiarized sources constituting the book's chapters are given in bold font. Other plagiarized sources are in regular font.

\section{Chapter 1: Spiritual Health in Nursing Practices}

Ruder, S. (2013). Spirituality in nursing. Nurses' perceptions about providing spiritual care. Home Healthcare Nurse, 31, 356-367. 
Chapter 2: When the End Is Only the Beginning: Extraordinary Experiences Observed in Palliative Care

Alvarado, C. S. (2006). Neglected near-death phenomena. Journal of NearDeath Studies, 24, 131-151.

Ethier, A. M. (2005). Death-related sensory experiences. Journal of Pediatric Oncology Nursing, 22, 104-111.

O'Connor, D. (2003). Palliative care nurses' experience of paranormal phenomena and their influence on nursing practice. Presentation at the 2nd Global Making Sense of Dying and Death Interdisciplinary Conference, November 21-23, 2003, Paris, France.

\section{Chapter 3: The Transformative Experiences of "Sensitive Nurses"}

Brayne, S., Lovelace, H., \& Fenwick, P. (2008). End-of-life experiences and the dying process in a Gloucestershire nursing home as reported by nurses and care assistants. American Journal of Hospice \& Palliative Medicine, 25, 195-206.

Ethier, A. M. (2005). Death-related sensory experiences. Journal of Pediatric Oncology Nursing, 22, 104-111.

Nahm, M., Greyson, B., Kelly, E. W., \& Haraldsson E. (2012). Terminal lucidity: A review and a case collection. Archives of Gerontology and Geriatrics, 55, $138-142$.

O'Connor, D. (2003). Palliative care nurses' experience of paranormal phenomena and their influence on nursing practice. Presentation at the 2nd Global Making Sense of Dying and Death Interdisciplinary Conference, November 21-23, 2003, Paris, France.

Chapter 4: "Windows to the Beyond": The Dreams and Visions of the End of Life

Brayne, S., Lovelace, H., \& Fenwick, P. (2008). End-of-life experiences and the dying process in a Gloucestershire nursing home as reported by nurses and care assistants. American Journal of Hospice \& Palliative Medicine, 25, 195-206.

Fenwick, P., Lovelace, H., \& Brayne, S. (2010). Comfort for the dying: Five year retrospective and one year prospective studies of end of life experiences. Archives of Gerontology and Geriatrics, 51, 173-179.

Nosek, C. L., Kerr, C. W., Woodworth, J., Wright, S. T., Grant, P. C., Kuszczak, S. M., Banas, A., Luczkiewicz, D. L., \& Depner, R. M. (2015). Endof-life dreams and visions: $A$ qualitative perspective from hospice patients. American Journal of Hospice \& Palliative Medicine, 32, 269-274. 
Chapter 5: Experiences at the End of Life in Nursing Homes of the Elderly

Brayne, S., Lovelace, H., \& Fenwick, P. (2008). End-of-life experiences and the dying process in a Gloucestershire nursing home as reported by nurses and care assistants. American Journal of Hospice \& Palliative Medicine, 25, 195-206.

Nahm, M., Greyson, B., Kelly, E. W., \& Haraldsson E. (2012). Terminal lucidity: A review and a case collection. Archives of Gerontology and Geriatrics, 55, $138-142$.

\section{Chapter 6: The Near-Death Experience as an End-of-Life Event}

Foster, R. D., James, D., \& Holden, J. M. (2009). Practical application of research on near-death experiences. In J. M. Holden, B. Greyson, \& D. James (Eds.), The handbook of near-death experiences: Thirty years of investigation (pp. 235-258). Praeger/ABC-CLIO.

Greyson, B. (2007). Near-death experiences. In E. Cardeña, S. J. Lynn, \& S. C. Krippner (Eds.), Varieties of anomalous experience: Examining the scientific evidence (pp. 315-352). American Psychological Association.

Holden, J. M. (2009). Veridical perception in near-death experiences. In J. M. Holden, B. Greyson, \& D. James (Eds.), The handbook of near-death experiences: Thirty years of investigation (pp. 185-211). Praeger/ABCCLIO.

Chapter 7: Spirituality in the Visions of the Dying

Alvarado, C. S. (2006). Neglected near-death phenomena. Journal of NearDeath Studies, 24, 131-151.

Betty, S. (2006). Are they hallucinations or are they real? The spirituality of deathbed and near-death visions. Omega, 53, 37-49.

Chapter 8: Death and Dying: Palliative Care and Spirituality

Westera, D. A. (2017): Spirituality in nursing practice. Springer (plagiarized sections are taken from pp. 295-314).

\section{Conclusion}

Brayne, S., Lovelace, H., \& Fenwick, P. (2008). End-of-life experiences and the dying process in a Gloucestershire nursing home as reported by nurses and care assistants. American Journal of Hospice a Palliative Medicine, 25, 195-206.

McDonald, C., Murray, C., \& Atkin, H. (2014). Palliative-care professionals' experiences of unusual spiritual phenomena at the end of life. Mental Health, Religion \& Culture, 17, 479-493. 


\section{APPENDIX 2}

\section{List of Publications by Alejandro Parra Known to Contain Plagiarism}

\section{Books:}

1. Book on Argentinian survey among nurses, published in different languages (see Appendix I for the true sources of the content):

a. 2021 Parra, A. L'ultime transition: Le monde médical face à l'après-vie. Agnières: JMG Editions.

b. 2019 Parra, A. The last farewell embrace: Spirituality, near-death experiences, and other extraordinary events among nurses. New York: Nova Science Publishers. (Retracted by publisher)

c. 2019 Parra, A. El último abrazo de despedida: Experiencias paranormales de enfermeras. Ediciones Luciérnaga.

2. 2019 Parra, A. Neurociencias en la frontera de lo paranormal. Madrid: Kier.

3. 2014 Parra, A. Alucinaciones: Experiencia o trastorno? Buenos Aires: Teseo, Universidad Abierta Interamericana.

4. 2009/2011 Parra, A. Percepciones imposibles (Doctoral Thesis). Saarbrücken: Editorial Académica Española.

5. 2009 Parra, A. El mundo oculto de los suenos. Buenos Aires: Kier.

\section{Articles and Book Chapters:}

6. 2020 Parra, A., \& Giudici, R. Cognitive-perceptual features associated with nonconventional healing practices. Imagination, Cognition and Personality: Consciousness in Theory, Research, and Clinical Practice, o(o), 1-17.

7. 2020 Parra, A., \& Giudici R. Experiencias senso-perceptuales en las practicas de sanacion: Estudio de encuesta. Ciencias de la Conducta, 35, 85-118.

8. 2020 Parra, A. Dreams, death and spirituality. Fortean Times, 398, 40-45.

9. 2020 Parra, A. Nurses' unusual hospital experiences. FATE, 734, 74-79.

10. 2019 Parra, A. Negative experiences in childhood, parental style, and resilience among people reporting paranormal experiences. Journal of Nervous and Mental Disease, 207, 264-270.

11. 2019 Parra, A. Berichte von Krankenpflegerinnen über außergewöhnliche Erfahrungen: Eine Studie zu Persönlichkeits-, Wahrnehmungs- und kognitiven Faktoren. Zeitschrift für Anomalistik, 19, 347-363. (Retracted by publisher)

12. 2018 Parra, A. Experiences at the end of life in nursing homes. EdgeScience, 33, 12-17. (Retracted by publisher)

13. 2018 Parra, A., \& Argibay, J. C. El constructo de "limite" y experiencias anómalas en psíquicos. Persona, 21, 45-59.

14. 2017 Parra, A., \& Giménez Amarilla, P. Anomalous/paranormal experiences reported by nurses in relation to their patients in hospitals. Journal of 
Scientific Exploration, 31, 11-28. (Retracted by publisher)

15. 2016 Parra, A., \& Argibay J. C. The boundary construct and anomalous experiences in psychics. Journal of the Society for Psychical Research, 80, 13-23.

16. 2016 Parra, A., \& Giménez Amarilla, P. Relación entre estrés laboral, alucinación y experiencias anómalas entre profesionales de enfermería. Revista Ciencia y Ciudado, 13, 22-40.

17. 2015 Parra, A., \& Argibay J. C. Sensibilidad psiquica: Evidencia empirica y experimental. In A. Parra (Ed.), Ojos invisibles. La cruzada por la conquista del espiritu (pp. 253-254). Buenos Aires: Antigua.

18. 2013 Parra, A. Análisis fenomenológico de la imaginería sensorial en las experiencias hipnagógica e hipnopómpica. Persona, 16, 165-186.

19. 2011 Parra, A. Thinking styles of psychic claimants. Australian Journal of Parapsychology, 11, 61-71.

20. 2010 Parra, A., \& Villanueva, J. Unusual perceptual experiences and ESP under psychomanteum stimulation: Imagery/hallucination proneness and schizotypal personality measures. Australian Journal of Parapsychology, 10, 41-59.

21. 2007 Parra, A., \& Argibay, J. C. "Token object" effect and medical diagnosis: An experimental study. 5oth Annual Convention of the Parapsychological Association, Proceedings of Presented Papers, pp. 95-102.

22. 2006 Parra, A., \& Villanueva, J. Exploring psychomanteum as a psiconducive state of consciousness. 49th Annual Convention of the Parapsychological Association, Proceedings of Presented Papers, pp. 141152. 